\title{
Culture and motivation in English for hospitality students: Why integrative motivation may be essential
}

\author{
Laura V. Fielden ${ }^{1}$ \\ Universidad de Extremadura \\ Mercedes Rico \\ Universidad de Extremadura
}

\begin{abstract}
Hospitality students are the future negotiators of cultural interaction in our field, and how they imagine culture through their language studies is important. In particular, cultural concepts form an essential part of their motivation to learn a foreign language, in so far as it indicates their willingness to integrate into another culture, as Gardner $(1960 ; 2007)$ and Dörnyei $(2001 ; 1994)$ have demonstrated. In fact, this integrative motivation has been recognized as one of the key elements for a successful learning outcome in languages. Our research explores whether integrative motivation is ubiquitous in the English for hospitality classroom. In a study with 51 adult English for Hospitality students, it found that students saw culture as malleable and showed a mixed motivational orientation. Based on these findings, relevant curriculum implications are discussed. Apart from having the necessary practical skills required in the industry, hospitality students and workers also need to be effective communicators by understanding the roots of cultural awareness and the possibility of having more than one cultural identity.
\end{abstract}

Keywords: Hospitality, Motivation, English for Specific Purposes, Culture, Integrative, Adults

\section{RESUMEN}

Estudiantes de programas de hostelería y restauración deberán dominar la interacción cultural en su campo profesional, por lo que el concepto de negociación y entendimiento cultural debe estar estrechamente ligado al estudio de la lengua. En concreto, los conceptos culturales forman una parte esencial de la motivación para aprender idiomas extranjeros.

Corresponding author - Facultad de Educación. Despacho A-20. Universidad de Extremadura. Avda de Elvas S/N. 06006 Badajoz. Spain 
La motivación integral aparece como uno de los elementos claves para el éxito en el aprendizaje de idiomas en distintos ámbitos y especialidades (Gardner (1960; 2007) y Dörnyei (2001; 1994). En este contexto, nuestra investigación explora si la motivación integral es ubicua en el aula de inglés para fines profesionales. En un estudio con 51 adultos cursando módulos de inglés profesional aplicado al sector hotelero, se observa que los alumnos entienden a la cultura como cambiable, y demuestran una motivación mixta hacia el aprendizaje lingüístico (integral e instrumental). A partir de las conclusiones extraídas, se presentan implicaciones curriculares para el desarrollo del inglés para fines ocupacionales en el aula. Más allá de tener las competencias lingüísticas necesarias, los estudiantes y futuros trabajadores de hostelería necesitan comunicarse de forma efectiva, entendiendo el concepto de multiculturalidad, y siendo conscientes de la importancia de la identidad cultural.

Palabras claves: Hostelería, Motivación, Inglés para fines específicos, Cultura, Motivación integral, Adultos

\section{Introduction}

The hospitality field is a multicultural one by necessity, since it denotes the business of entertaining or housing guests who hail from both near and far. Students desiring to work successfully in this field nowadays must be prepared not simply to be able to communicate linguistically with such guests, but also to communicate with them interculturally. This involves a range of knowledge and skills that may begin simply with greeting someone using appropriate body language.

These future professionals must expect to interface successfully with cultural differences in order to do their jobs well (Božinović, \& Joško, 2013; Luka, Vaidesvarans, \& Vinklere, 2013; Yoganjana, Menike, \& Pathmalatha, 2015), as they interact with a variety of peoples in their daily tasks at reception desks, in restaurants or tourism bureaus, to name a few. Though it has long been recognized that the skills needed for this work are not simply linguistic, research into the cultural component of language learning has lagged (Kiełbasiewicz \& Radko, 2006; Gannon, 2008; Ntukula, 2013; Grobelna, 2016). "This oversight curtails the opportunities for companies to leverage their knowledge and expertise across their international portfolios and limits the long-term competitive nature of hospitality and tourism management education" (Gannon, p.2).

That is why bridging nationalities and cultures through English as a lingua franca for hospitality students has led English language instructors in the field to focus on the importance of showing respect to diverse cultures, identities, and needs (Alsagoff, 2012). Learning a second language thus is not just a question of subject matter acquisition but also of engaging users in a dynamic understanding of another culture, where motivation to get to know this culture plays a key role (Dörnyei, 2001; Gardner, 2007). 
Without such motivation, learners may not start the learning process and for those who have begun, it may be hard to maintain their expectations once they encounter their first difficulties (Dörnyei, 2001; Gardner, 2007; Palmer, 2009). Consequently, highly motivated learners have been found to demonstrate higher achievement in learning English than those with lower motivation (Bernaus \& Gardner, 2008; Bernaus, Wilson, \& Gardner, 2008; Fan \& Feng, 2012; Kitjaroonchai, 2012). What is more, English for Specific Purposes learners have been shown to tend toward instrumental motivation, in other words a motivation associated with a specific objective related to a practical purpose, such as passing an exam, obtaining a certified level, or getting a job. This sort of motivation may end once the objective is in sight.

In this line of thought, a pillar of motivational theory in foreign language study relies on instrumental versus integrative motivation as understood by Gardner and Lambert's research (1972). This is an interesting area to examine not simply because of its foundational importance in second and foreign language acquisition motivational research, but also because it gets at the heart of what makes language study different from other academic fields: culture, an area that has long been ignored in English for Specific Purposes (Barron, 1991) but which is key for hospitality students and a fundamental ingredient of integrative motivation. Language learning involves assimilating cultural difference and the cultural context in which the language occurs can have an effect on the students' attitudinal reaction to language learning (Gardner, 2007; Stars, 2012).

Gardner's theories on motivation in language learning have had a major impact on research despite criticisms (Olshtain et al., 1990). McIntyre (2002), citing the large amount of evidence over the years that integrative factors are essential to positive motivation, suggests that the integrative reasons to learn a language should be divided into integrativeness and motivation. In this division, integrativenes begins with the cultural beliefs present in the socio-cultural context, within an environment that fosters positive cultural attitudes within the learning environment at least, by teachers as representatives of the target language group. In this way, language instructors can help raise students' motivation and interest in the foreign language as they relate the sounds, vocabulary and structures of a foreign language to real people and settings (Fenner, 2008).

What is more, scholars working in other areas of motivation in education have found that the rigidity of students' cultural stereotypes, and the degree to which they feel stereotypes are always true, have an important relationship with students' beliefs that they can learn and are intelligent, which can affect their motivation toward a class subject (Steele, 1997; Dweck, 2006, p. 89-94, Rattan, Savani, Chugh, \& Dweck, 2015; Levy, Stroessner, \& Dweck, 1998). So, we can conclude that instructors need to 
focus not only on what learners know about culture, but also on the cultural beliefs and perceptions that language learners bring into the classroom and how those influence their motivational patterns.

In this study, we will investigate this key area for hospitality students by posing two lines of research: the role of integrative motivation in language for hospitality studies and the students' beliefs concerning culture itself in terms of its malleability. This is an area which needs more attention since the majority of motivational studies in English for Specific Purposes (ESP) focus on instrumental motivation (AlTamimi \& Shuib, 2009; Kyriacou, \& Zhu, 2008; Xu, 2008), due perhaps to the emphasis made on ESP courses' supposed functionality (Hutchinson \& Waters, 1987). In particular our study examines how perceptions of cultural malleability and integrative motivation operate within a group of 51 adult, English for hospitality learners studying in non-formal courses offered by the public employment agency in Extremadura, Spain. This is a population of interest since it is understudied but proliferating in a difficult world economy where the hospitality and tourism fields are leading much of the economic recovery (Bharwani \& Butt, 2012; World Travel and Tourism Council, 2015, p. 3,). This is particularly pertinent to our setting in Spain. The World Economic Forum listed Spain as the most competitive Travel and Tourism country in 2015 (World Economic Forum, 2015) and employment in the tourism sector in Spain contributed to 1 in 7 jobs in 2015 when the sector grew 3,7\% over the previous year by seeing a record number of visitors to the country, 68 million in 2015 (Costantini, 2016).

\section{Theoretical Framework}

\subsection{Culture in tourism and hospitality studies}

Globalization has affected the tourism industry in myriad ways, making diversity a strategic component of the tourism and hospitality industries. Cross-cultural training is necessary for employees to learn how to handle certain situations raised by customers from diverse cultures, religions, and ethnicities. What is more, a glance at sobering current events points to a growing critical need to understand and teach diversity. The ailing global economy needs international cooperation to resolve acute financial problems occurring against a backdrop of dire social and political trends. These trends reveal a growing anti-immigrant, anti-foreigner mindset, a socially solidified rejection of the "other" according to the UNESCO Director (Bokova, 2015):

Today again, cultural diversity is under attack by violent extremists who lay waste to the heritage and persecute minorities. These crimes confirm still 
further our conviction that the enemies of human dignity will always seek to destroy cultural diversity, because it is the symbol of free thought and the infinite creativity of the human being.

This rejection endangers the tenuous but essential webs of cooperation that modern societies have formed around very diverse cultural origins.

Language is the glue for international cooperation. Far more than just a written or verbal code, language involves social practices of interpreting and coding meaning, a fundamental relationship between language and culture. An understanding of language as 'open, dynamic and constantly evolving' (Shohamy, 2007, 5) taps the rich complexities of communication and makes educational experience engaging for students. In this sense, language is not just a thing to be studied but a way of seeing and communicating about the world, not simply a body of knowledge to be learnt but a social practice and culture in which to participate (Kramsch, 1994). This was recognized early on by Hymes (1971) and was a tenet of Canale and Swain's second language acquisition model (1980) where one of the four principal communicative competences is the Sociolinguistic Competence, which involves knowing the cultural expectations that exist in speaking the foreign language. Understanding the nature of this relationship between language and culture is central to the process of learning another language in hospitality studies, since it develops an awareness of the ways in which culture interrelates with language (Liddicoat, Papademetre, Scarino, \& Kohler, 2003). Despite receiving attention in language education, there are still important gaps in how to teach the culture and language relationship, as López (2016, p. 106) notes:

One of the most significant problems is that we, perhaps inadvertently, may indeed reinforce stereotypes because, instead of fostering ICC (Intercultural Communication), we often focus exclusively on the language as communication, while the context in which that communication occurs, and which gives meaning to the messages, is often relegated to second place. It is, thus, necessary to understand what we mean by the culture that needs to be promoted in class.

Citron (1993) discusses the need to teach ethno-lingual relativity in language learning, which is having a perspective "that is not limited by one's own cultural and linguistic experiences, but rather is open to the contrasting cultural and linguistic patterns of other peoples" (p.1), indicating that an openness to other cultural experiences facilitates the acquisition of linguistic structures that are different from one's own, since language is "culture-bound", and as such expresses ideas that may exist singularly in a given culture and may not exist or be important in another.

Showing cultural awareness promotes communicative competence and enhances English fluency (Alsamani, 2014, López, 2016; Ziesing, 2001; Shumin, 2002, p. 214, 
220). Ziesing for example found a positive correlation between Thai university EFL students' English levels and their cultural "literacy", how much they knew about English speaking cultures in different areas, including popular and intellectual culture and humor. Jones indicates that the more students wish to identify with native speakers the more likely they are to sound like native speakers and have a more correct pronunciation (Jones, 2002, p. 194).

In language classes, in this case English for hospitality students who would feasibly manage cultural interactions with international clients, this is clearly a priority. In this context, intercultural and cultural self-awareness would enable students to work in situations where diverse cultural backgrounds are present, managing their interactions more effectively and monitoring cultural differences which affect language transactions. Without such competencies, misunderstandings are liable to proliferate.

As a first objective, this study inquired into students' integrative motivation, the degree to which someone desires to be integrated into the foreign culture in some way. The desire to integrate into the foreign culture plays an important role in language acquisition, as will be discussed further in the next section. Secondly, it inquired into the degree to which students found cultural characteristics to be malleable. The malleability of cultural characteristics is a first step in any culturally integrative process, since assuming these can change allows one to loosen her or his own cultural ties while approximating those of the new language's culture. The studies of Levy, Stroessner and Dweck (1998) on cultural stereotypes and fixedgrowth mindsets in the classroom examine the idea of cultural malleability as important to growth mindsets and sustaining learning goals (Dweck, 2006), but this has not yet been linked to integrative motivation or considered for ESP students.

\subsection{Integrative and instrumental motivation in ESP Hospitality students}

Students might not be aware of a cultural underpinning to their motivation to learn English, mainly if they feel their presence in a language class is mostly to fulfill class requirements, to get a better job, or for another pragmatic value. These reasons for learning English are usually called instrumental (Gardner, 1972). Instrumental motivation places more emphasis on "the practical value and advantages of learning a new language" (Lambert, 1974). In their important work on ESP learners, Hutchinson and Waters (1987), when reviewing integrative and instrumental motivation and its importance to ESP learners, call instrumental motivation a "reflection of an external need" which does not address learner's enjoyment or desire to learn (though these may be present, too), but simply indicates that learning is need-driven. 
On the other hand, an integrative motivation is in essence the desire to integrate into a culture, including simply having positive reactions to it. Integrative motivation has been one of the most consistent predictors for foreign language success (Hernandez, 2008; Masgoret \& Gardner, 2003). In particular, integrativeness encapsulates a key difference in how foreign language motivation is inherently not like motivation for other academic subjects: It implies the meeting and recognition of cultures and self in a way mathematics or science simply does not. This cultural identity originates simultaneously in the learner, in the people who regularly speak the foreign language, and in the intersection between them in the classroom. Dörnyei (1994) described this as: “...the multifaceted nature and role of language (i.e., the fact that it is at the same time a communication coding system, an integral part of the individual's identity, and the most important channel of social organization (p. 519).

Early on, integrativeness was defined by Gardner (1960) as "an open interest in the other language group, and/or outgroups in general or a willingness to identify with the group" that speaks the language being learnt (p. 13). Though this research began in the context of second language study in Canada, it has been linked to foreign language study definitively (Dornyei, 1994). Integrativeness includes how culture is understood and taught in the ESP classroom, from textbook snippets on gastronomy to having native pen friends across the ocean. As Big C and Little C culture has become standard in language teaching, English instructors become cultural representativesn of the target language group in the classroom, though little research has been done to indicate the best way to manage this representative role for students' effective learning.

This is despite the fact that research has shown that developing integrative motivation aids students' learning. Gardner wrote that testing for integrativeness was "intended to assess attitudinal reactions applicable to the learning of a second language which involves the other language community or other groups in general" (1960, p. 13). Gardner and Lambert found (1972) that the degree to which students were more integratively motivated was positively correlated, though not exclusively so, with their success in learning the language, and that integrative orientations tended to register more positively than did instrumental ones where the student desired to use the language for some instrumental purpose, such as getting a job, etc. This correlation is indirect, and is mediated through motivation. This is to say that students who were positively motivated and integratively orientated were more likely to be successful in learning a foreign language. Empirically, this model, known as the social-educational model, is extremely well supported, a fact to which numerous scholars have attested (Macintyre, Mackinnon, \& Clément, 2009; Skehan, 1989). Integrative factors have emerged strongly both in bicultural and in 
monocultural contexts, and in various countries and learning environments. Integrativeness has been found to be an important variable in predicting motivated behavior and success in language learning in numerous different studies: (Dörnyei, 2005; Dörnyei \& Csizér, 2005; Clément, Dörnyei, \& Noels, 1994; Shaaban \& Ghaith, 2000; Wen, 1997; Kraemer, 1993; Yashima, 2002; Bonney, Cortina, Smithdarden, \& Fiori, 2008).

Integrative/instrumental motivational orientations have been examined in studies for ESP learners, though not in the field of hospitality. Often, the results of these studies show a tendency toward instrumental orientations (Al-Tamimi \& Shuib, 2009) which are focused on obtaining a certificate or proof of study, in particular in Asia (Kyriacou, \& Zhu, 2008; Xu, 2008). This is interesting given that most EFL and ESL populations examined in this light show a more integrative motivation (Samad, Etemadzadeh, \& Far, 2013). Bobkina, Domínguez \& Fernandez de Caleya (2013) found for example that 72 engineering students taking English for Industrial Engineering Technical University of Madrid had very high instrumental reasons for learning English, where 98,6\% indicated they needed English for their specific career (very much and a lot).

Students' motivation toward foreign language acquisition can influence their learning outcomes since it might determine the time of exposition to the language as well as the way they learn. In order to reach the more proficient levels required for hospitality students, learners must persist in their students. Motivation has been linked to study persistence (Ramage, 1990) and in particular study persistence has been linked to integrative motivation, particularly in higher levels of proficiency, for example in learning Japanese as a foreign language (Matsumoto \& Obana, 2001). Zoltan Dornyei (2002) stated that the learner's enthusiasm, commitment and persistence are key determinants of success or failure.

To summarize, since motivation and culture are key areas for language learning, they are important to students of English for specific, academic and general purposes. They are also logically essential to future hospitality professionals, since integrative motivation is based on the assimilation of new cultures, and these students are more likely to be expected to apply cultural awareness in their jobs in the hospitality sector. In understanding their motivation to study English and their attitudes toward culture, instructors will be better prepared to equip them as future professionals. 


\section{Study: Integrative motivation for hospitality students in non- formal, adult courses in Spain}

\subsection{Research questions and objectives}

Motivation for second language acquisition is a very thoroughly researched area, however it is not often studied within the English for Specific Purposes scope for non-formal, adult students. We were not able to find studies in terms of the importance of integrative motivation in the international hospitality sector, in particular. Integrative orientations, based on a desire to integrate into another culture in some way, are key to these learners since they are more frequently expected to interact with persons from different cultures. This is especially interesting in light of the fact that the few studies on ESP students' integrative/instrumental motivation reveal that they tend to show more instrumental motivation, in general $(\mathrm{Xu}, 2008)$. What is more, ESP hospitality students are more often expected to actually interact with international clients in a productive sense in terms of using speaking skills, one of the most anxietyproducing skills in acquiring another language (Cheng, Horwitz \& Schallert, 1999; Khan \& Zafar, 2010; Sioson, 2011; Tum, 2015). For this reason, we focused on the following objectives and research questions:

Objective 1: Explore students' motivational orientations as integrative or instrumental. How much integrative motivation do students show at the beginning of a new course in English for hospitality services?

Objective 2: Analyse student beliefs concerning the malleability of cultural characteristics. The malleability of cultural characteristics would precede any sort of integration.

\subsection{Methodology}

\subsubsection{Participants}

The participants in this study were adults taking continuing education courses in a public hospitality school in Extremadura, Spain. These courses were sponsored by SEXPE (Servicio Extremeño Público de Empleo), the public administrative branch for employment in the region of Extremadura, were free to the public and reserved $40 \%$ of their places for the unemployed. However, in these groups there was a higher percentage of unemployed students: around $70 \%$ of the students in these courses were looking for work when the study was undertaken. The courses were two English for Restaurant Service (A1-A2 level) courses, (90-hour courses) and English 
for Tourism (A2) (120 hours) for a total of 51 participants in the sample group. The course methodology utilized communicative strategies in teaching the four skills, with special emphasis on oral skills, and the evaluation system was continuous through portfolios, which was graded pass/fail. Each course included a practical speaking component where students had to serve clients in an on-site cafeteria and restaurant in English. Finally, the textbook chosen, English for International Tourism (Pearson, 2002), was chosen for its inclusion of cultural points. It had at least one section per chapter dedicated to a cultural topic, real work scenarios in hospitality, and used photos and maps from well-known travel guidebooks to create a more realistic study environment.

The students took part in the study voluntarily and included a diverse range of ages and educational backgrounds: a little less than half of the group was universityeducated $(\mathrm{N}=22)$, followed by high school studies and vocational education. In terms of sex distribution, the majority of the participants were women ( $N=29)$. As for the age, we found a larger group of 35 and under $(\mathrm{N}=33)$, but also an important band of persons between 36-40 years of age.

\subsubsection{Instruments and materials}

The instrument utilized in the study was a Student Opinion Questionnaire designed for this purpose concerning student beliefs and motivation. This questionnaire was first tested in a pilot group of 21 different students who took the same courses one semester earlier. The pilot phase served to prune item length and clarify wording. In this same phase, test validity was obtained by requesting commentary and suggestions from two experts in the field of psychology, both familiar with the constructs and the purpose. Once the pilot phases had been finished, the questionnaire was tested for reliability. The ratio used for this purpose was Cronbach's alpha (Triola, 2006), indicating internal consistency of items. The majority of experts agree that the standard for test reliability begins at 0.6 (Malhotra, 2004). The calculation performed concluded with a 0.795 alpha. Given that this index ranges between 0 and 1 , which is above the standard 0.6 , the reliability of the beliefs questionnaire can be considered appropriate.

In order to address the first objective on integrative or instrumental motivation, the opinion questionnaire had items concerning motivational orientations as mostly instrumental or integrative, and used a semantic differential response scale (Osgood, 1957), asking respondents to signal their answers by marking one spot on an unnumbered continuum. These scales are similar to Likert scales in that by adding up individual items one can reach a multi-item score. In this type of visual scale students can interpret the worded options at each extreme as leanings toward 
one side or another, with a clear neutral response in the middle, as seen below:

Above all, I study English in order to:

Get a job $\square: \square: \square: \square: \square: \square: \square$ : Relate to native speakers

Develop myself professionally $\square: \square: \square: \square: \square: \square: \square$ : Expand my cultural knowledge

Improve my future job opportunities $\square: \square: \square: \square: \square: \square: \square$ : Meet native speakers

Receive economic benefits $\square: \square: \square: \square: \square: \square: \square$ : Participate in cultural activities To address the second objective concerning the malleability of cultural characteristics as a precursor to being able to culturally integrate, students were asked to rate the following:

According to my experience cultural stereotypes are:

True $\square: \square: \square: \square: \square: \square: \square:$ False

and people's cultural characteristics are:

Changeable $\square: \square: \square: \square: \square: \square: \square:$ Not changeable

Static $\square: \square: \square: \square: \square: \square: \square$ : Modifiable

Malleable $\square: \square: \square: \square: \square: \square: \square$ : Fixed

\subsubsection{Procedure and administration}

Students were administered the Student Opinion Questionnaire approximately one week after the course began. This was administered in class, by their teacher, where students were told that their participation was voluntary.

\subsubsection{Statistical analysis}

Statistical analysis was conducted using SPSS software, version 19, which is used to quantitatively describe the main features of a collection of data. Given that the variables of the questionnaires are measured here on numerical scale these are considered ordinal variables and so determine the kind of contrast that can be employed. We should note as well that the population under study here was 
reduced and does not reflect a normal distribution, which indicates that the appropriate statistical method for this study is non-parametric, i.e., it does not depend on the population fitting any parameterized distributions.

\section{Results}

4.1 Objective 1: Explore students' motivational orientations as integrative or instrumental

As discussed, acquiring a foreign language involves not only learning to undertake linguistic exchanges but also having a better understanding of cultural differences, given that language and culture are inextricably connected. Hospitality students are expected to interface with culture frequently. Institutions teaching hospitality courses need consequently to maximize student learning in order to yield positive results in language acquisition, a goal which can be achieved by assessing what motivates students to study a second language and implementing teaching strategies which incorporate these motivational forces into the language curriculum. Since integrativeness is generally more desirable for foreign language acquisition, the following graph shows the items in terms of integrative statements, with 7 being the most integrative for each item, and 35 being the highest possible total for the sum of all the items. In this sense, the lighter colored bars in graph (Figure 4) below represent the maximum punctuation for each item listed, as well as the maximum punctuation for the items' total sum, while the darker gray bars represent the actual scores of the students in this study.

\section{I study English in order to:}

Integrativeness TOTAL / Instrumentalness TOTAL

To participate in cultural activities / Receive economic benefits

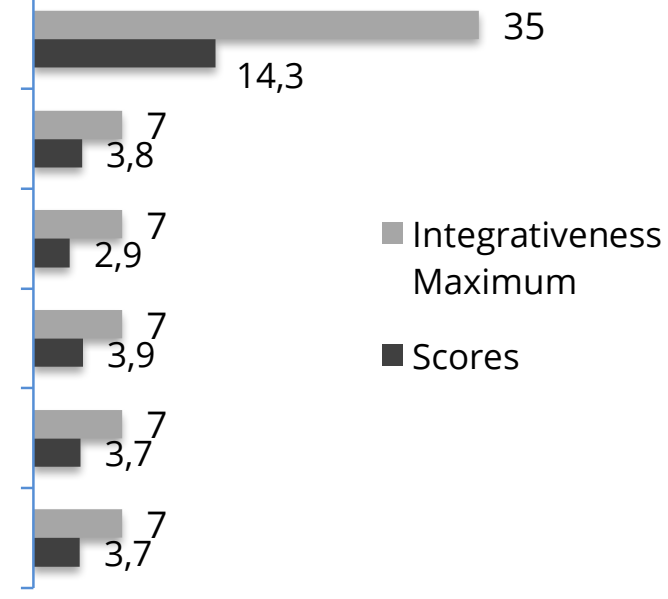

To meet native speakers / Improve my future job opportunities

To expand my cultural knowledge / Develop myself professionally

To relate to native speakers / Get a job For pleasure / Out of necessity.

Integrativeness Maximum

Scores

Figure 1. Instrumental or integrative motivations of students. 
In Figure 1 we can see the results both at the individual item level, and in the sum of the items, where a score of 35 would be the most integrative result for the total of the items, and 1 would be the most instrumental. The average group score for these students for the total block of items was 14 points out of 35 total points, 35 again being the most integrative for the total block, so that students' responses were slightly more instrumental overall.

In terms of the individual items, where a score of 1 for each item would be the most instrumental response, and 7 would be the most integrative, one can appreciate in Figure 1 that most responses were slightly below a neutral 4 on the scale.

Objective 2: Analyze student beliefs concerning the malleability of cultural characteristics.

\section{Students' Beliefs about Culture}

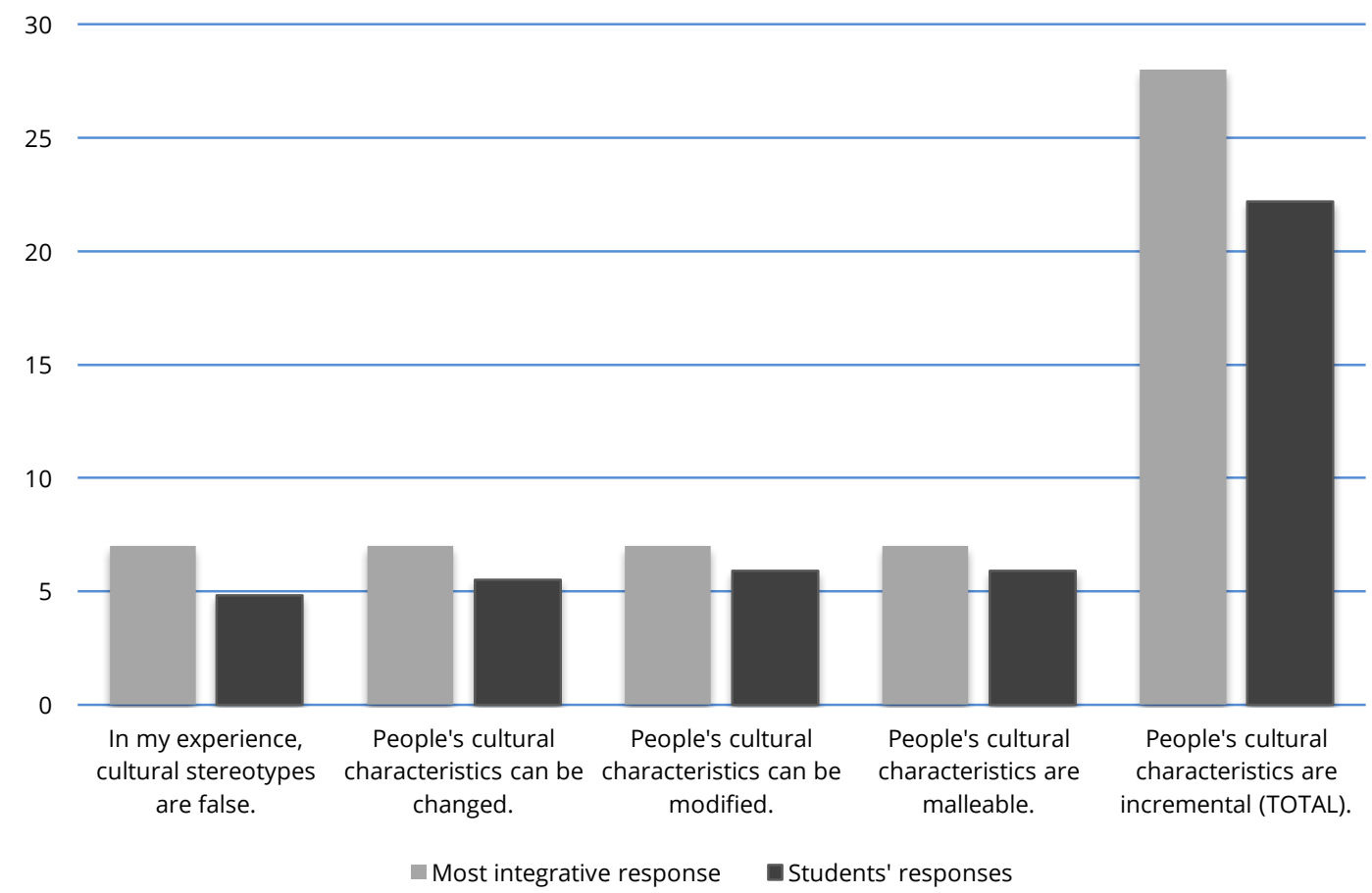

Figure 2. What students believe about culture and its ability to change.

The second section focused on culture and students' beliefs concerning the malleability of cultural characteristics. As previously noted, this is not an area typically included in language motivation studies, though research in educational psychology has revealed it is relevant to how students' form and pursue learning 
goals (Dweck, 2000). General beliefs about culture are key to language learning since culture is what makes learning language distinct from other subjects. In Figure 5, below, again the most integrative response is shown in light gray as the most desirable, a 7 on the scale of 1-7, and the students' actual responses in the study are shown in dark gray.

In general students' responses were on the integrative side, ranking around 5-6 on the 7-point scale.

\section{Discussion}

As seen in the results for the first objective, which was to explore students' motivation as mostly instrumental or integrative, the students participating in English modules for hospitality services in this study showed a slight, but important tendency toward instrumentality, most clearly seen in the item on taking the course to improve future job opportunities. Instrumental motivation is common in ESP students, as has been noted in other studies, so this echoes previous findings. One might wonder why the responses were not more definitively more instrumental, as they were for other ESP studies, such as for Xu (2008) and Bobkina, Dominguez and Fernandez de Caleya (2013). Falling into a more driven instrumental motivation does not mean that students have little interest in learning but that teaching has to be flexible to their needs. This particular response may have to do with the conditions surrounding the course itself, as one designed to provide skills to adults seeking to improve their employability.

In this sense, a more instrumental motivation also speaks to the current economic situation in Spain and the type of class under study here: public, free courses operated by the regional employment agency for a group of students of whom approximately $70 \%$ or more were unemployed at the time. It may be that ESP students, more than ESL or EFL students, seek a direct link from their studies to the work field, an approach often adopted in ESP courses and transmitted to its students, as Hutchinson and Waters (1987) discussed. This affects curriculum development, where a course may limit itself to acquiring only concrete lexical items, for example. A danger here is to assume the goal of learning English for a specific purpose streamlines and thus simplifies the learning process, the learning goals, and indeed the learner, to the detriment of other skills.

Such a simplification risks ignoring affective factors, like motivation, which are key to foreign language acquisition. Numerous studies already cited here have demonstrated the benefits of integrative motivation in language learning. Students with higher integrative motivation tend to persist further in their studies and reach 
more proficient language levels, which is useful, if not necessary, in the hospitality field. Integrative motivation is considered a positive predictor for foreign language success overall, where students who were positively motivated and integratively orientated were more likely to be successful in learning a foreign language (Dörnyei, 2005; Dörnyei \& Csizér, 2005; Clément, Dörnyei, \& Noels, 1994; Shaaban \& Ghaith, 2000; Wen, 1997; Kraemer, 1993; Yashima, 2002; Bonney, Cortina, Smithdarden, \& Fiori, 2008).

Importantly, integrative motivation is essential for ESP students in the hospitality field, since being able negotiate intercultural differences is important to future job success as they interact with international clients. The expectation is that they will work frequently with people from a variety of cultures, and have to use more active, and thus more difficult, skills (speaking) to do so. On the one hand, a more integrative motivation includes cultural awareness and appreciation, seen in the items included in the study's scale (Meet native speakers; Participate in cultural activities, etc), both elements that would clearly help ESP students succeed in the tourism industry as they manage real-time international interactions. On the other hand, integrative motivation assumes a more integral (pleasure based) response from the learner to the language being learnt, indicating a more personal investment to the process. This is also especially important to ESP learners in the field given the extremely high turn-over rate in tourism.

In the second objective and research question, we asked if students saw cultural characteristics as malleable, which would point to the initial feasibility of this integration. They indicated overall that cultural characteristics were malleable. So, in this sense students saw cultural characteristics as able to be changed or modified. The lowest-marked item here was that cultural stereotypes are false, which is interesting. If it is commonly accepted that most cultural stereotypes are true, then culture is understood to be more fixed than malleable, and so one's ability to culturally integrate cannot be expected to be very thorough or fluid.

Students who tend toward believing in the rigid applicability of cultural stereotypes were found to have more rigid concepts of intelligence and their own learning (Levy, Stroessner, \& Dweck, 1998; Dweck, 2000) which caused students study anxiety and affected their overall academic success. What is more, for ESP students, the importance of understanding culture as malleable points to a key awareness for language learning, where language is, as Citron writes, "culturally-bound", expressing what is most salient to a given culture and distinguishing it from others. Students need to be able to understand this culturally-bound aspect to language learning in order to navigate the semantic and lexical differences they will encounter between their own language and English. These differences ultimately reveal that not all aspects of a foreign language are necessarily translatable into their own and vice 
versa, but rather that language exists in a determined, social context. This contributes to students being able to contextualize language expressions more successfully, which can extend to understanding and applying cultural expressions, phrasal verbs, the use of certain tenses in determined contexts, etc. An awareness of the relativity of culture also encourages an understanding of one's own cultural conditions as socially constructed, an awareness which naturally promotes flexibility in cultural encounters and facilitates international interactions where different cultures meet.

Integrative motivation, as discussed, is based on the idea that cultural characteristics are malleable, that one can have multiple cultural identities, and that it is positive to integrate into English-speaking culture. Gardner and others' studies show that high levels of integrative motivation relate positively to foreign language acquisition. So, this sort of belief, that cultural stereotypes are mostly true, would work against integrative mindsets, clearly, and perhaps cause conflict in a hospitality post, where cultural interactions occurred frequently.

Though further research must be done, we can conclude that ESP students for whom language learning is more need-driven require help developing integrative motivation and an awareness of culture as malleable and socially dependent that will bolster their language learning experience and make it more successful. The hospitality ESP context of learning English may be one of the best laboratories for working with integrative motivation, since it easily translates to contexts which demand interaction with real people on a day-to-day basis.

As stated in the theoretical framework, the combination of language and culture is central to the process of learning languages in hospitality studies given the acute need these professionals will have to actively apply their language skills in real-time. These students are being trained to use language as a tool to manage a host of important client needs in a variety of feasibly complex service contexts which is why educators should adopt pedagogical strategies to incorporate integrative and cultural motivational into the language curriculum and to develop an awareness of the ways in which culture interrelates with language, a particularly acute need given the times we live in today.

\subsection{Limitations and further research}

The questionnaires employed in this study were not designed to be used as assessment tools in and of themselves, and as such student responses cannot be considered a diagnosis. Additionally, students participating in this study were a small, self-selected group and present a non-random sample. The fact that students 
made a distinction when asked about stereotypes is interesting and merits further study, so this area should be included in future studies concerning the role of cultural stereotypes in hospitality students' language studies.

\section{Conclusions}

In the field of hospitality, in particular in ESP for hospitality, this study expands current research by examining Spanish students' motivation to learn in a key area: instrumental/integrative orientations. Earlier research has not focused on ESP students in this sector. The study results point, like other ESP studies before it, toward a slight tendency toward instrumental motivation. It also showed interesting results for how these hospitality students understand cultural characteristics and their ability to be changed. This is an area which has not yet been considered important to integrative motivation but which is essential in determining the degree to which cultural integration is feasible. In general students indicated that cultural characteristics were malleable, which is positive for integration. They also indicated that cultural stereotypes were somewhat true, which may complicate any realistic idea of integration and points to the need for more research into this concept.

This study signals several key factors that should be taken into consideration in reshaping future ESP courses in hospitality. The first of these is the importance of integrative motivation for these students who will be expected to successfully negotiate interactions with persons from different cultures. Instead of resigning ourselves to the idea that ESP courses, due to the relevance of their content, perhaps, tend to produce or attract instrumentally-motivated students, we should consider how to foster and foment integrative motivation to their benefit.

A plethora of research shows that integrative motivation is more beneficial to effective language learning overall, and it must surely be beneficial to hospitality students expected to interact culturally in the near future. In this sense, either in course format or content, or both, integrative motivation should be a goal in ESP classes in the hospitality sector where face-to-face social interaction is expected. A second important area for consideration in curriculum development is the concept of cultural characteristics as malleable, which Dweck and others (Dweck, 2006, p. 8994, Rattan, Savani, Chugh, \& Dweck, 2015; Levy, Stroessner, \& Dweck, 1998; Steele, 1997; López, 2016) relate to the retention of cultural stereotypes. We should move beyond the mere recognition of cultural diversity as positive and introduce ESP students to a more theoretical understanding of culture and its fluid nature. This should include an awareness that culture in itself is malleable, leading to the possibility of individuals wearing multiple, changeable, cultural identities. This can allow us to focus more sharply on the process of the formation and retention of 
cultural stereotypes. Further, for hospitality students, courses should contemplate how such stereotypes affect their interactions when working with international clients.

\section{About the authors}

Dr. Laura V. Fielden teaches in the Department of English Philology at the University of Extremadura (Spain), where she engages with students from multiple disciplines, including from Education and ESP (undergraduate / postgraduate levels). She is a member of the GexCALL research group (http://gexcall.unex.es/en), and is interested in technological applications for language teaching as well as the implications of these for motivation in the classroom.

Dr. Mercedes Rico is a Professor in the Department of English Philology at the University of Extremadura (Spain), institution where she has been teaching Information Technology applied for Language Learning, English for Computer Science and Communication Skills in Engineering for more than 25 years (undergraduate /postgraduate levels). Being coordinator of the GexCALL research group (http://gexcall.unex.es/en), her main research include ESP/EOP, multimodal discourse and ICT applied to L2.

\section{Acknowledgements}

The authors would like to thank the students and staff at the ESHAEX for their time and collaboration.

\section{Article history}

Paper received: 4th May 2017

Paper received in revised form and accepted for publication: 24th November 2017 


\section{References}

Al-Tamimi, A., \& Shuib, M. (2009). Motivation and attitudes towards learning English: A study of petroleum engineering undergraduates at Hadhramout University of Sciences and Technology. GEMA Online Journal of Language Studies, 9(2). Retrieved from: <http://www.ukm.my/ppbl/Gema/pp\%2029 55.pdf >

Alsagoff, L. (2012). Identity and the EIL learner. In L. Alsagoff, S. L. McKay, G.Hu, and W.A. Renandya (Eds.), Principles and practices for teaching English as an international language (pp. 104-122). New York: Routledge.

Alsamani, A. (2014). Foreign culture awareness needs of Saudi English language majors at Buraydah community college. English Language Teaching, 7(6), 143-153.

Barron, C. (1991). Material thoughts: ESP and culture. English for Specific Purposes, 10(1), 173187.

Bernaus, M., \& Gardner, R. (2008). Teacher motivation strategies, student perceptions, student motivation, and English achievement. The Modern Language Journal, 92(3): 387401.

Bernaus, M., Wilson, A., \& Gardner, R. (2008). Teachers' motivation, classroom strategy use, students' motivation and second language achievement. Porta Linguarum, 12, 25-36.

Bharwani, S. \& Butt, N. (2012), "Challenges for the global hospitality industry: an HR perspective", Worldwide Hospitality and Tourism Themes, 4, (2), 150-62.

Bobkina, J., Domínguez Romero, E. \& Fernández De Caleya, M. (2013). Motivation and Attitudes towards English Language Learning Tertiary Education: A Contrastive Approach to Undergraduate Response to English as a Core Subject in the Engineering and Humanities Degrees. RIDE 10.

Bokova, I. (2015). Message from Ms. Irinia Bokova, Director-General of UNESCO. World Dat for Cultural Diverty, for Dialogue and Development. Retrieved from: <http://www. unesco.org/new/en/cultural-diversity-day>.

Bonney, C., Cortina, K., Smithdarden, J., \& Fiori, K. (2008). Understanding strategies in foreign language learning: Are integrative and intrinsic motives distinct predictors? Learning and Individual Differences, 18(1), 1-10. doi:10.1016/j.lindif.2007.11.005

Božinović, N., \& Sindik, J. (2013). Language proficiency for careers in tourism and learning different second foreign languages. Turizam, 17(3), 121-130. Retreeved from: $<$ http://www.dgt.uns.ac.rs/turizam/arhiva/vol_1703_3.pdf >

Canale, M., \& Swain, M. (1980). Theoretical bases of communicative approaches to second language teaching and testing. Applied Linguistics, 1, 1-47.

Cheng, Y. Horwitz, E., \& Schallert, D. (1999), Language Anxiety: Differentiating writing and speaking components. Language Learning, 49, 417-446. doi: 10.1111/0023-8333.00095).

Citron, J. (1993). The Role of Ethno-Lingual Relativity in Second Language Acquisition. Working 
Papers in Educational Linguistics 9(2), 29-41.

Clément, R., Dörnyei, Z., \& Noëls, K. (1994). Motivation, self-confidence, and group cohesion in the foreign language classroom. Language Learning, 44, 418-448.

Constantini, L. (2016, January 12). El turismo consolida su repunte por el tirón de la demanda interna. El País. Retrieved from <www.elpais.com>.

Csizér, K. \& Dörnyei, Z. (2005). Language learners' motivational profiles and their motivated learning behavior. Language Learning 55(4), 613-659.

Dörnyei, Z. (1994). Motivation and motivating in the foreign language classroom. The Modern Language Journal, 78(3), 273-284.

Dörnyei, Z. (2001). Motivational strategies in the language classroom. Cambridge: Cambridge University Press.

Dörnyei, Z. (2002). The motivational basis of language learning tasks. In P. Robinson (Ed.), Individual differences and instructed language learning (pp. 137-158). Amsterdam: John Benjamins. Reprinted in: K. Van den Branden, M. Bygate, J. M. Norris (Eds.), Task-based language teaching: A reader (pp. 357-377). Amsterdam: John Benjamins.

Dörnyei, Z. (2005). The psychology of the language learner: Individual differences in second language acquisition. Mahwah, New Jersey: Lawrence Erlbaum Associates.

Dörnyei, Z. \& Csizér, K. (2005). The effects of intercultural contact and tourism on language attitudes and language learning motivation. Journal of Language and Social Psychology, 24(4), 327-357. doi: 10.1177/0261927X05281424

Dubicka, I., \& O'Keeffe, M. (2002). English for International Tourism: Pre-Intermediate Student's Book. Chicago: Pearson.

Dweck, C. (1989). Motivation. In A. Lesgold and R. Glaser (Eds.), Foundations for a psychology of education (Vol. 1., pp. 87-136). Hillsadale, NJ: Erlbaum.

Dweck, C. (2006). Mindset: The new psychology of success. New York: Ballantine Books.

Rattan, A., Savani, K., Chugh, D., \& Dweck, C. (2015). Leveraging mindsets to promote academic achivement: Policy recommendations. Perspectives on Psychological Sciences, 10(6), 721-726. Retrieved from: <http://journals.sagepub.com/doi/pdf/10.1177/17456916 $15599383>$.

Fan, J., \& Feng, H. (2012). A study on students' learning motivation of EFL in Taiwanese vocational college. International Journal of Learning and Development, 2(3), 260-269.

Fenner, A. (2008). Cultural Awareness in the Foreign Language Classroom. In Cenoz, J. and Hornberger, N. (Eds.). Encyclopedia of Language and Education. 6, 273-285

Gannon, J. (2008). Developing Intercultural Skills for International Industries: The Role of Industry and Educators. Hospitality, Leisure, Sport and Tourism Network: Enhancing Series: Internationalisation.

Gardner, R. (1960). Motivational variables in second-language acquisition. (Doctoral dissertation). McGill University. 
Gardner, R. \& Lambert, W. (1972). Attitudes and motivation in second language learning. Rowley, MA: Newbury House.

Gardner, R. (2007). Motivation and Second Language Acquisition. Porta Linguarum, 8, 9-20.

Hymes, D. (1971). On communicative competence. In J. Pride and J. Holmes (Eds.), Sociolinguistics. Penguin, 1972. (Excerpt from the paper published 1971, Philadelphia, University of Pennsylvania Press.)

Grobelna, A. (2016). Intercultural Challenges Facing the Hospitality Industry. Implications for Education and Hospitality Management. Journal of Intercultural Management, 7(3), pp. 101117. Retrieved 11 Nov. 2016, from doi:10.1515/joim-2015-0023

Hernández, T. (2008). Integrative Motivation as a Predictor of Success in the Intermediate Foreign Language Classroom. Foreign Language Annals. 39(4), 605-617.

Hutchinson, T., \& Waters, A. (1987). English for Specific Purposes. Cambridge: Cambridge University Press.

Khan, Z. \& Zafar, S. (2010). The effects of anxiety on cognitive processing in English language learning. English Language Teaching, 3(2), 199-209.

Kiełbasiewicz-Drozdowska I., \& Radko S. (2006), The role of intercultural communication in tourism and recreation, "Studies In: Physical Culture and Tourism", 13(2), pp. 75-85.

Kitjaroonchai, N. (2012). Motivation toward English language learning of students in secondary and high schools in education service area office 4, Saraburi province, Thailand. International Journal of Language and Linguistics, 1(1), 22-33.

Kraemer, R. (1993). Social psychological factors related to the study of Arabic among Israeli high school students: A test of Gardner's socio-educational model. Studies in Second Language Acquisition, 15, 83-104.

Jones, R. (2002). Beyond 'listen and repeat': Pronunciation teaching materials and theories of second language acquisition. In Richards, J., \& Renandya, W., Eds. Methodology in Language Teaching: An Anthology of Current Practice. P. 194.

Kramsch, C. (1994). Context and culture in language teaching. Oxford: Oxford University Press.

Kyriacou, C. \& Zhu, D. (2008). Shanghai pupil's motivation towards learning English and the perceived influence of important others. Educational Studies. 34(2), 97-104.

Lambert, W. (1974). Culture and language as factors in learning and education. In F.E. Aboud and R.D. Mead (Eds.), Cultural factors in learning and education. Bellingham, WA: Fifth Western Washington Symposium on Learning.

Levy, S., Stroessner, S., \& Dweck, C. Stereotype formation and endorsement: The role of implicit theories. Journal of Personality and Social Psychology, 74(6), Jun 1998, 1421-1436. http://dx.doi.org/10.1037/0022-3514.74.6.1421

Liddicoat, A., Papademetre, M., Scarino, A., \& Kohler, M. (2003). Report on Intercultural Language Learning. Canberra: Department of Education Science and Training. Australian 
Government.

López Rocha, S. (2016). Intercultural communicative competence: creating awareness and promoting skills in the language classroom. In C. Goria, O. Speicher, \& S. Stollhans (Eds), Innovative language teaching and learning at university: enhancing participation and collaboration.(pp. 105-111). Dublin: Research-publishing.net. http://dx.doi.org/10.14705/ rpnet.2016.00041

Luka I., Vaidesvarans S., Vinklere D. (2013). Educating Tourism Students for Work in a Multicultural Environment. Journal of Teaching in Travel and Tourism, 13(1), pp. 1-29.

Maclntyre, P., Mackinnon, S., \& Clément, R. (2009). Toward the development of a scale to assess possible selves as a source of language motivation. In Z. Dörnyei \& E. Ushioda (Eds.), Motivation, Language Identity and the foreign language Self (pp. 172-192). London: MPG Books.

Malhotra, N. (2004) Marketing Research: An Applied Orientation. (4thedn) Pearson Education, Inc: New Jersey.

Masgoret, A., \& Gardner, R. (2003). Attitudes, motivation, and second language learning: A meta-analysis of studies conducted by Gardner and associates. Language Learning, 53(S1), 167-210.

Matsumoto, M. \& Obana, Y. (2001). Motivational factors and persistence in learning Japanese as a foreign language. New Zealand journal of Asian studies, 3(1), 59-86

Mclntyre, P. (2002). Motivation, Anxiety and Emotion in Second Language Acquisition. In Peter Robinson (ed.) Individual Differences and Instructed Language Learning (pp. 45-68). Amsterdam/Philadelphia: John Benjamins Publishing Company.

Ntukula, A. (2013) Diversity in the workplace: Managing a culturally diverse workforce in the Irish hospitality sector. Masters thesis, Dublin, National College of Ireland.

Olshtain, E., Shohamy, E., Kemp, J., \& Chatow, R. (1990). Factors Predicting Success in EFL among Culturally Different Learners. Language learning, 40, 23-44. http://dx.doi.org/ $\underline{10.1111 / j .1467-1770.1990 . t b 00953 . x}$

Osgood, C. The nature and measurement of meaning. In: Osgood CE, Tannenbaum H, Suci GJ, editors. The measurement of meaning. University of Illinois Press; Urbana: 1957. pp. 3-41.

Palmer, D. (2009). Student interest generated during inquiry skills lesson. Journal of Research in Science Teaching 46(2):147 - 165.

Pinang, P. (2006). Integrative motivation: how perceptions of the target language country influence students' motivational pattern. A Paper Presented at the Science and Art of Language in Teaching International Conference Malaysia

Ramage, K. (1990), Motivational Factors and Persistence in Foreign Language Study*. Language Learning, 40: 189-219. doi:10.1111/j.1467-1770.1990.tb01333.x

Litvin, S., Goldsmith, R.E., \& Pan, B. (2005). Electronic Word of Mouth in Hospitality and 
Tourism Management. Tourism Management (29)3, 458-468.

Samad, A., Etemadzadeh, A., \& Far, H. (2013). Motivation and language proficiency: Instrumental and integrative aspects. Procedia- Social and Behavioural Sciences 66(7), 432440.

Shaaban, K., \& Ghaith, G. (2000). Student motivation to learn English as a foreign language. Foreign Language Annals, 33, 632-644.

Shohamy, E. (2007). Language policy: Hidden agendas and new approaches. New York: Routledge.

Shumin, K. (2002). Factors to consider: Developing adult EFL students' speaking abilities. In J. C. Richards, \& W. A. Renandya (Eds.), Methodology in Language Teaching: An Anthology of Current Practice (pp. 204-211). Cambridge: Cambridge University Press. http://dx.doi.org/10.1017/CBO9780511667190.028

Sindik, J. \& Božinović, N. (2013). Importance of foreign languages for a career in tourism as perceived by students in different years of study. Vitez-Tuzla-Zagreb-Beograd-Bucharest 15 (31). Retrieved from: <http://hrcak.srce.hr/file/159702>

Sioson, I. (2011). Language learning strategies, beliefs, and anxiety in academic speaking tasks. Phillipine ESL Journal, 7(July), 3-27.

Skehan, P. (1989). Individual differences in second-language. London: Edward Arnold.

Stars, J. (2012). Initiating Integrative Motivation for Learning foreign language Using ICT $5^{\text {th }}$ Internationa Conference ICT on language learning. Available at <http://conference. pixelonline.net/ICT4LL2012/>

Steele, C. (1997). A threat in the air: How stereotypes shape intellectual identity and performance. American Psychologist, 52 (6), 613-629 DOI: 10.1037//0003-066X.52.6.613

Triola, M. 2006. Elementary Statistics, $10^{\text {th }}$ Edition. Pearson, Boston.

Tum, D. (2015). Foreign language anxiety's forgotten study: The case of the anxious preservice teacher. TESOL Quarterly, 49 (4), 627-658. DOI: 10.1002/tesq.190

Wen, X. (1997). Motivation and language learning with students of Chinese 1. Foreign Language Annals, 30(2), 235-251. doi:10.1111/j.1944-9720.1997.tb02345.x

World Economic Forum. (ND). Travel and Tourism Competitiveness Report 2015.Retrieved from: $<$ http://reports.weforum.org/travel-and-tourism-competitiveness-report-2015/indexresults-the-travel-tourism-competitiveness-index-ranking-2015/>

$\mathrm{Xu}, \mathrm{X}$. (2008). Influence of instrumental motivation on EFL learners in China and its implication on TEFL instructional design. Educational Communications and Technology Papers of the University of Saskatchewan. http://www.usask.ca/education/coursework/ 802papers/xu/index.htm.

Yashima, T. (2002). Willingness to communicate in a second language: the Japanese EFL context. Modern Language Journal, 86(i), 54-66.

Yoganjana, H., Menike, S., \& Pathmalatha, K. Developing Foreign Language Competencies of 
Tourism Industry Oriented Undergraduates in Sri Lanka. Tourism, Leisure and Global Change 2, TOC-74. Papers from the 7th Tourism Outlook Conference/Tropical Tourism Outlook Conference, 8-10 August 2014.

Ziesing, M. (2001). Cultural literacy and language fluency. In A Collection of Academic Papers: In Celebration of the 20th Anniversary of the University of the Thai Chamber of Commerce, 1-14. Bangkok, Thailand: University of the Thai Chamber of Commerce. 


\section{Appendix}

Sample of the corpus used in this work (Peraita \& Grasso, 2010) 